\title{
Minireview
}

\section{The Soil Microbial Biomass: Concept, Measurement and Applications in Soil Ecosystem Research}

\author{
PHILIP BROOKES ${ }^{1 *}$ \\ ${ }^{1}$ Agriculture and Environment Division, IACR-Rothamsted Experimental Station, Harpenden, Herts AL5 2JQ, \\ $U K$
}

(Received May 9, 2001—Accepted July 6, 2001)

For many purposes the soil micro-organisms can be considered as a single pool of living soil organic matter (the soil microbial biomass). Current methods to measure the microbial biomass are described and their merits and demerits discussed. The concept of the microbial biomass as a living soil organic matter pool is illustrated by reference to it as a labile reservoir of potentially plant-available nutrients. An estimate of the turnover times of biomass carbon $(\mathrm{C})$ of 0.94 years and of biomass phosphorus $(\mathrm{P})$ of 0.39 years shows that the turnover rates of nutrients within the biomass may be quite different. An understanding of the dynamics of biomass $\mathrm{P}$ is important. The lack of $\mathrm{P}$ availability in many tropical agricultural soils has been described as 'the bottle-neck of world hunger'. Even if $\mathrm{P}$ is supplied it may be rapidly and irreversibly fixed in these, usually, strongly P-fixing soils. By adding small rates of animal manures with the fertilizer, more biomass $\mathrm{P}$ is formed. During the process of biomass turnover, this $\mathrm{P}$ may be released slowly and taken up by the crop more efficiently. Thus, in a Kenyan P-fixing soil, crop yields were much larger when both manure and fertilizer $\mathrm{P}$ were given than when either were applied singly.

Key words: Microbial biomass measurements, microbial biomass $\mathrm{P}$ and $\mathrm{C}$

The soil microbial biomass comprises all soil organisms with a volume of less than about $5 \times 10^{3} \mu \mathrm{m}^{3}$, other than living plant tissue, and can thus be considered as the living part of soil organic matter. Jenkinson ${ }^{15)}$ eloquently described it as "the eye of the needle through which all the organic materials must pass" as they are broken down to simple inorganic components including water, carbon dioxide, nitrate, phosphate and sulphate, that plants can use again.

Because it is living, the microbial biomass responds much more quickly to changing soil conditions, particularly decreases or increases in plant or animal residues, than does soil organic matter as a whole. Measurable changes in microbial biomass may thus reflect changes in soil fertility, due, for example, to changing soil management, long before such changes are reflected in changes in the total pool of

\footnotetext{
* Corresponding author; E-mail: philip.brookes@bbsrc.ac.uk, Tel: +44-15827-63133, Fax: +44-15827-60981
}

soil organic matter.

The biomass, although comprising only about 1 to $4 \%$ of total soil organic matter, is an important labile reservoir of essential plant nutrients, e.g. nitrogen $(\mathrm{N})$, phosphate $(\mathrm{P})$ and sulphate $(\mathrm{S})$. In arable Northern European soils it can easily contain $100 \mathrm{~kg} \mathrm{~N} \mathrm{ha}^{-1}$ and up to 2 or 3 times more in grassland or woodland soils. It is now widely accepted that the fertility of both natural and agricultural ecosystems frequently depends upon the nutrients being very efficiently cycled within the organic pools of plants, microbes and organic matter. The biomass is thus both a sink and source of nutrients, which become available during the process of biomass turnover.

\section{The microbial biomass concept}

There have been many studies of individual soil microorganisms grown either in vitro or in soil under axeinic conditions. However, in terms of studying soil nutrient dynam- 


\section{The microbial biomass concept}

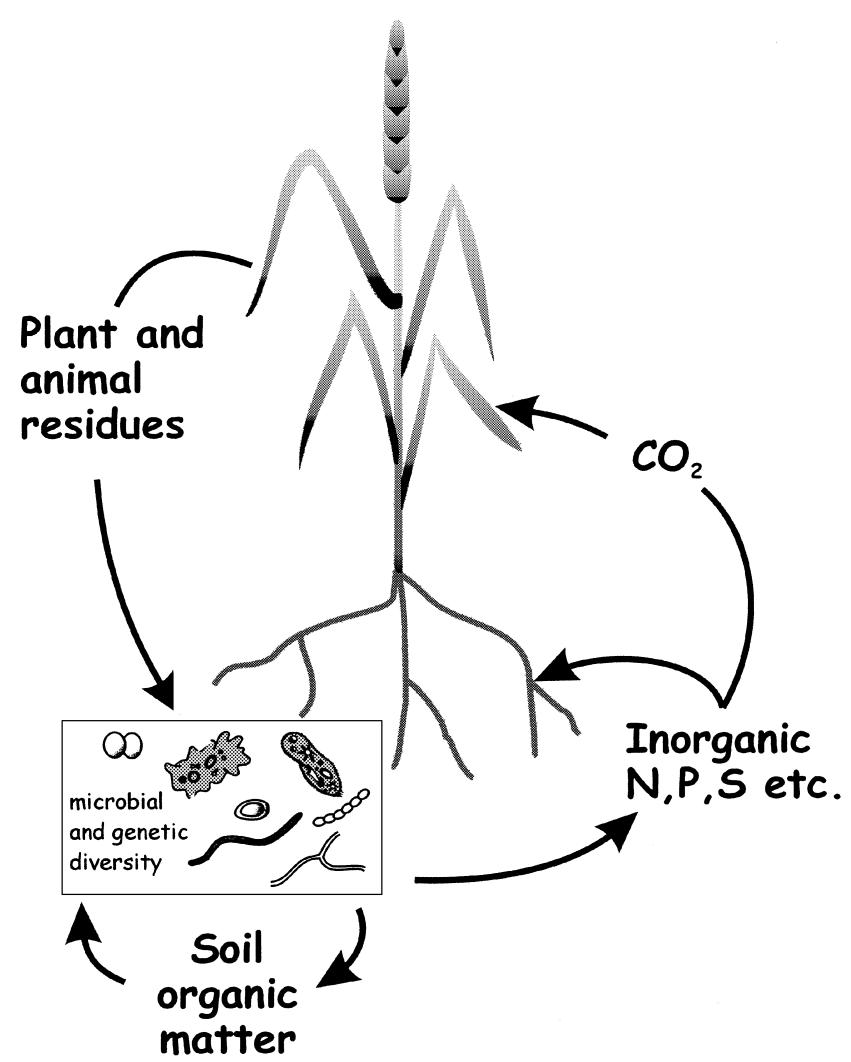

Fig. 1. The role of the microbial biomass in the cycling of plant nutrients.

ics, work with single species, or even a cluster of species of micro-organisms has not been generally useful. Exceptions include mycorrhizae and Rhizobium which have very specialised functions. Part of the problem is that so few soil micro-organisms have yet been identified and many cannot be cultured. Another problem is that soil microbial activity resulting, for example, in carbon dioxide $\left(\mathrm{CO}_{2}\right)$ evolution, $\mathrm{N}$ mineralization or immobilization, is the net result of complex interactions between the many thousands of microbial species and the many thousands of organic compounds, which, together, comprise soil organic matter.

As with organic matter itself, using a 'black box' approach-measuring the microbial biomass as a single, undifferentiated unit ${ }^{19}$ __ has proved surprisingly useful in studying soil organic matter dynamics. I hope to illustrate these concepts further in this paper. In doing this, I am mindful of the development of powerful techniques in molecular biology which will enable us to study the survival and biology of single microbial species in whole soil, with its full suite of organisms intact ${ }^{12}$. This approach will al- most certainly increase our understanding of microbial survival in soil, and of the factors controlling specific processes. However, for ecosystem studies and investigations into carbon or nutrient flows that result from large consortia of microbes processing a wide range of substrates, the 'black box' approach, in which the microbial population is treated as an undifferentiated whole, still has much to offer.

Here I outline some of the methods that we have developed to measure the soil microbial biomass. I also attempt to show what these methods have revealed about some of the characteristics of the biomass and about its role in the maintenance of soil fertility.

\section{Measuring the soil microbial biomass}

\section{Direct microscopic counting}

Microscopic counting is still the most direct method of estimating the amount of microbial biomass in soil, but is technically difficult and completely unsuitable for routine use. Thin films are prepared from an agar-soil suspension, mounted on microscope slides and then treated with an appropriate stain. Phenolic aniline blue is often used as it stains protein and is thus considered to give an estimate of the entire population. The numbers and sizes of spherical organisms and the lengths and diameters of fungal hyphae are measured and converted to total biomass by using conversion factors for specific gravity, percentage carbon content and percentage dry matter, obtained from micro-organisms grown in vitro. Other stains, especially fluorescent ones like fluoroscein isothiocyanate or acridine orange, are much easier to count with but do not stain the full range of organisms. This method is discussed in more detail by Jenkinson et al. ${ }^{20)}$ and Jenkinson and Ladd ${ }^{16)}$.

\section{Fumigation-Incubation method}

Jenkinson and Powlson ${ }^{19)}$ showed that more $\mathrm{CO}_{2}$ was evolved from a soil fumigated with chloroform, following fumigant removal and aerobic incubation, than from a similar non-fumigated soil. They subsequently showed that this extra $\mathrm{CO}_{2}$ (the $\mathrm{CO}_{2}$ flush) came from the microbial cells, killed by $\mathrm{CHCl}_{3}$, as they were decomposed by the subsequent recolonizing population. They suggested that measurement of the $\mathrm{CO}_{2}$ flush could provide an estimate of the amount of biomass in soil.

The standard Fumigation-Incubation (FI) method uses soil, first incubated at $40-50 \%$ water-holding capacity (WHC) for $7-10$ days at $25^{\circ} \mathrm{C}$, then given a 24 hour fumigation with ethanol-free $\mathrm{CHCl}_{3}$, followed by fumigant removal and a 10 day aerobic incubation of the soil following readjustment to $50 \%$ WHC. Biomass $\mathrm{C}\left(\mathrm{B}_{\mathrm{c}}\right)$ is then calculated 
from: $\mathrm{B}_{\mathrm{c}}=\mathrm{F}_{\mathrm{c}} / k_{\mathrm{c}}$ where $\mathrm{F}_{\mathrm{c}}=\left[\left(\mathrm{CO}_{2}-\mathrm{C}\right.\right.$ evolved from the fumigated soil $)]$ minus $\left[\left(\mathrm{CO}_{2}-\mathrm{C}\right.\right.$ evolved from the non-fumigated soil)], both over the 10 day period. The constant $k_{\mathrm{c}}$ is taken to be 0.45 under these conditions, on the basis that approximately $45 \%$ of the carbon in micro-organisms added to soils, followed by fumigation and incubation as described above, is evolved as $\mathrm{CO}_{2}$ in 10 days. This method has been widely used since its introduction and, provided the soils are first incubated as above, results are in quite good agreement with measurements obtained by direct microscopy ${ }^{20,39)}$. Biomass $\mathrm{C}$ measurements can be converted to total biomass by assuming that the biomass contains $45 \% \mathrm{C}$ on a dry weight basis.

The FI method cannot be used in soils that have recently been air-dried. Air-drying both kills some of the biomass and renders some non-biomass $\mathrm{C}$ decomposable ${ }^{36}$. In addition, FI measurements are unreliable in soils which contain much free $\mathrm{CaCO}_{3}$, soils which have recently received fresh substrates ${ }^{23)}$, waterlogged soils ${ }^{14)}$ or soils with a $\mathrm{pH}$ below about $4.5^{39)}$.

Biomass $\mathrm{N}$ can also be estimated similarly by measurement and appropriate calibration of the flush of inorganic $\mathrm{N}$ which also occurs during FI.

\section{Fumigation-Extraction method}

Vance et al. ${ }^{40)}$ first showed a close linear relationship between biomass $\mathrm{C}$ measured by $\mathrm{FI}$ and $\mathrm{E}_{\mathrm{c}}$, where $\mathrm{E}_{\mathrm{c}}=$ [(organic C extracted by $0.5 \mathrm{M} \mathrm{K}_{2} \mathrm{SO}_{4}$, from a $24 \mathrm{~h}$ fumigated soil) minus (organic $\mathrm{C}$ extracted from a similar, non-fumigated soil)]. They proposed that biomass $\mathrm{C}$ can be estimated from the relationship: Biomass $\mathrm{C}=2.64 \mathrm{E}_{\mathrm{c}}$.

The fumigation-extraction method (FE) does suffer from the disadvantage that comparatively small amounts of $\mathrm{C}$ have to be measured in $0.5 \mathrm{M} \mathrm{K}_{2} \mathrm{SO}_{4}$. Vance et al. ${ }^{40)}$ used a dichromate digestion method. However, the $\mathrm{C}$ can be more conveniently determined by an automated system using persulphate and U.V. oxidation, which gives essentially the same results but more rapidly and easily ${ }^{41)}$.

Chloroform fumigation also increases the amount of total $\mathrm{N}$ extractable with $0.5 \mathrm{M} \mathrm{K}_{2} \mathrm{SO}_{4}$. Brookes et al. ${ }^{7)}$ showed that this extra $\mathrm{N}$ also comes from the microbial biomass and proposed that biomass $\mathrm{N}$ could be estimated from the relationship: Biomass $\mathrm{N}=2.22 \mathrm{E}_{\mathrm{N}}$, where $\mathrm{E}_{\mathrm{N}}$ is analogous to $\mathrm{E}_{\mathrm{c}}$.

About $16 \%$ of the total $\mathrm{N}$ released by $\mathrm{CHCl}_{3}$ after $24 \mathrm{~h}$ and extracted by $\mathrm{K}_{2} \mathrm{SO}_{4}$ is in either ammonium-N or $\alpha$ amino $\mathrm{N}$. These forms react with ninhydrin giving a blue/ purple colour and measurement of ninhydrin-N can be used to estimate the amount of biomass $\mathrm{C}^{2}$.

Following $\mathrm{CHCl}_{3}$-fumigation there is also an increase in inorganic $\mathrm{P}\left(\mathrm{P}_{\mathrm{i}}\right)$ made extractable to $0.5 \mathrm{M} \mathrm{NaHCO}_{3}$. Brookes et $a l .{ }^{8)}$ reported that biomass $\mathrm{P}$ could be estimated from measurement of this increase in $\mathrm{P}_{\mathrm{i}}$, with a correction made to account for incomplete extraction of $\mathrm{P}_{\mathrm{i}}$ due to fixation on soil colloids etc. and assuming that about $40 \%$ of the $\mathrm{P}$ in the soil microbial biomass is extracted by $0.5 \mathrm{M}$ $\mathrm{NaHCO}_{3}$ following $\mathrm{CHCl}_{3}$-fumigation.

Sulphur is also released from the biomass during $\mathrm{CHCl}_{3}$ fumigation and its measurement after extraction can also be used to estimate biomass $\mathrm{S}^{10,33)}$.

The FE method offers some considerable advantages over FI. Biomass measurements can be made across the whole $\mathrm{pH}$ range ${ }^{39)}$, in soils containing actively decomposing substrates, e.g. cereal straw, both in the laboratory ${ }^{24)}$ and in the field ${ }^{25}$ and in freshly sampled soils, all conditions where FI is unreliable. Reliable biomass measurements by FE have also been reported in paddy (i.e. waterlogged) soils ${ }^{14}$.

As with FI, the FE method is suitable for use with isotope tracer studies. FE has the big advantage that the labelled biomass that develops as substrates decompose can be measured immediately after substrate addition ${ }^{26)}$. This is impossible with FI. In most situations FE has now replaced FI as the routine method to measure microbial biomass. However, FI remains the standard method against which all others are calibrated.

\section{Adenosine 5'-triphosphate}

Adenosine 5'-triphosphate (ATP) is only found in living cells and has a very short exocellular existence (a few hours) in soils. It can be quantitatively extracted from the biomass by ultrasonification in the presence of a highly acidic reagent (e.g. trichloroacetic acid, TCA) to inhibit phosphatase activity. The reagent we use ${ }^{17)}$ is comprised of an aqueous solution of paraquat $(0.25 \mathrm{M})$, sodium dihydrogen phosphate $(0.5 M)$ and trichloroacetic acid $(0.5 M)$. Following ultrasonics, the filtered soil extracts can be analysed immediately or stored frozen $\left(-18^{\circ} \mathrm{C}\right)$ for weeks or months. A set of extractants 'spiked' with a known quantity of ATP (usually 25 pmol $50 \mu^{-1}$ ) are extracted simultaneously. The partial recoveries of the 'spike' are used to correct for incomplete extraction of native microbial ATP. The ATP is finally assayed by the fire-fly luciferin-luciferase enzyme system using a bioluminometer or scintillation counter set to count 'out of coincidence'.

\section{Characteristics of the soil microbial biomass}

\section{Biomass size}

Measurements of soil microbial biomass $\mathrm{C}$ usually show that it comprises about 1 to $4 \%$ of soil organic $C$, with the 
largest proportions in grassland or woodland rather than arable soils. A more illuminating way of considering the biomass size is in terms of its fresh weight. The microbial biomass in the plough layer of the unfertilized plot of the Broadbalk Continuous Wheat Experiment at Rothamsted contains about $500 \mathrm{~kg} \mathrm{C} \mathrm{ha}^{-1}$. If we assume that living microbial cells contain $50 \% \mathrm{C}$ and $90 \%$ water then the total $\mathrm{C}$ immobilized in the cells of the biomass converts to $10 \mathrm{tha}^{-1}$ of living tissue. This is equivalent to approximately 100 sheep per hectare which gives some idea of the size of this population.

Only a very small proportion of the total species of micro-organisms in the biomass have been properly identified. It is almost certain that some of them (as yet unidentified) will have properties which are ultimately very useful (e.g. antibiotic production). For this, if no other reason, it is clearly in our best interest to conserve soil in a fully functioning state and avoid polluting it with heavy metals, or other toxic materials. While the expression "don't treat soil like dirt" is a much over-used cliché (and lecture title) in soil science, it does at least carry a useful message.

\section{The biomass as a sink-source of plant nutrients}

The soil microbial biomass can be considered as a labile pool of essential plant nutrients such as $\mathrm{N}, \mathrm{P}$ and $\mathrm{S}$, which are held in a form largely protected from loss due to leaching or fixation. Until the development of the fumigationextraction method it was not possible to quantify the sizes of the microbial pools of these nutrients as they developed during the early decomposition of crop or animal residues. This newer methodology made this possible ${ }^{24)}$.

There is evidence that the biomass may utilize nutrients preferentially from plant residues rather than from the soil nutrient pool ${ }^{26)}$. Thus, the composition and characteristics of plant residues will have a major influence on the availability of nutrients to crops and upon subsequent recycling. Factors such as substrate $\mathrm{C} / \mathrm{N}$ ratio, percentage of readily decomposable and resistant plant tissue or lignin content will have important effects upon the uptake and subsequent mineralization of nutrients in crop residues ${ }^{3)}$.

Therefore the correct management of crop residues and annual manures, while important enough in the generally more productive agriculture in temperate regions, is vital in managing soil fertility in the tropics. It is also clear that the fertility of both natural and agricultural tropical ecosystems depends upon the nutrients being very efficiently cycled within the organic pools of plants, microbes and soil organic matter. In this way, losses of nutrients from the ecosystem are minimised.
Table 1. Nutrients immobilized in the soil microbial biomass.

\begin{tabular}{lccc}
\hline & $\mathrm{C}$ & $\mathrm{N}$ & $\mathrm{P}$ \\
\hline & & $\mathrm{kg} \mathrm{ha}^{-1}$ & \\
\hline Broadbalk $^{\mathrm{a}}$ & & & \\
Unfertilized & 180 & 26 & 7 \\
NPK & 200 & 26 & 6 \\
Farmyard manure & 310 & 46 & 27 \\
Woodland & 570 & 84 & 54 \\
Highfield Grassland & 890 & 130 & 65 \\
\hline
\end{tabular}

a All 0-10 cm soil depth

Due to its large size, the amounts of nutrients, e.g. $\mathrm{N}$ and $\mathrm{P}$ immobilized in the cells of the microbial biomass are quite large (Table 1). They are also usually considerably larger in grassland than arable soils. This reflects the much larger annual inputs of $\mathrm{C}$ in grassland than in arable soils. In low-input soils, a large proportion of the plant-available nutrients, especially $\mathrm{N}, \mathrm{P}$ and $\mathrm{S}$, will be derived from the mineralization of nutrients immobilized within the cells of the microbial biomass.

\section{Soil microbial biomass as an early warning of changing soil conditions}

There is generally a reasonably close linear relationship between amounts of microbial biomass $\mathrm{C}$ and amounts of soil organic $\mathrm{C}$ in arable, grassland and woodland soils $^{4,6,13,16,23,29,31,35)}$. The soil microbial biomass increases or decreases in response to changes in soil management much more quickly than soil organic matter as a whole, where such changes can often take many years before being detectable by classical chemical analysis ${ }^{1,6,16)}$. Ayanaba et al. ${ }^{6}$ and Adams and Laughlin ${ }^{1)}$ reported that changing from forest or grassland to arable management caused much greater decreases in biomass $\mathrm{C}$ than total soil organic $\mathrm{C}$.

Powlson et al. ${ }^{28)}$ showed that 18 years of straw incorporation in two Danish field experiments (Studsgaard and Rønhave) caused 40-50\% increases in biomass $\mathrm{C}$ and $\mathrm{N}$ whereas total soil organic $\mathrm{C}$ and $\mathrm{N}$ only increased by $5 \%$, a statistically insignificant increase (Figs. 2-3). Both $\mathrm{CO}_{2}-\mathrm{C}$ evolution and $\mathrm{N}$ mineralization over the $0-60$ day period were significantly greater in the soils which had received straw than in control soils where the straw had been burnt. At Rønhave the increase in mineralized $\mathrm{N}$ was $38 \%$ and at Studsgaard $50 \%$ (Fig. 4). This is direct evidence that an increased rate of return of crop residues to soil increases the labile pool of soil organic matter where mineralization-immobilization occurs, to a much greater extent than the soil organic matter as a whole. Some of this $\mathrm{N}$ that is mineral- 


\section{STUDGAARD}
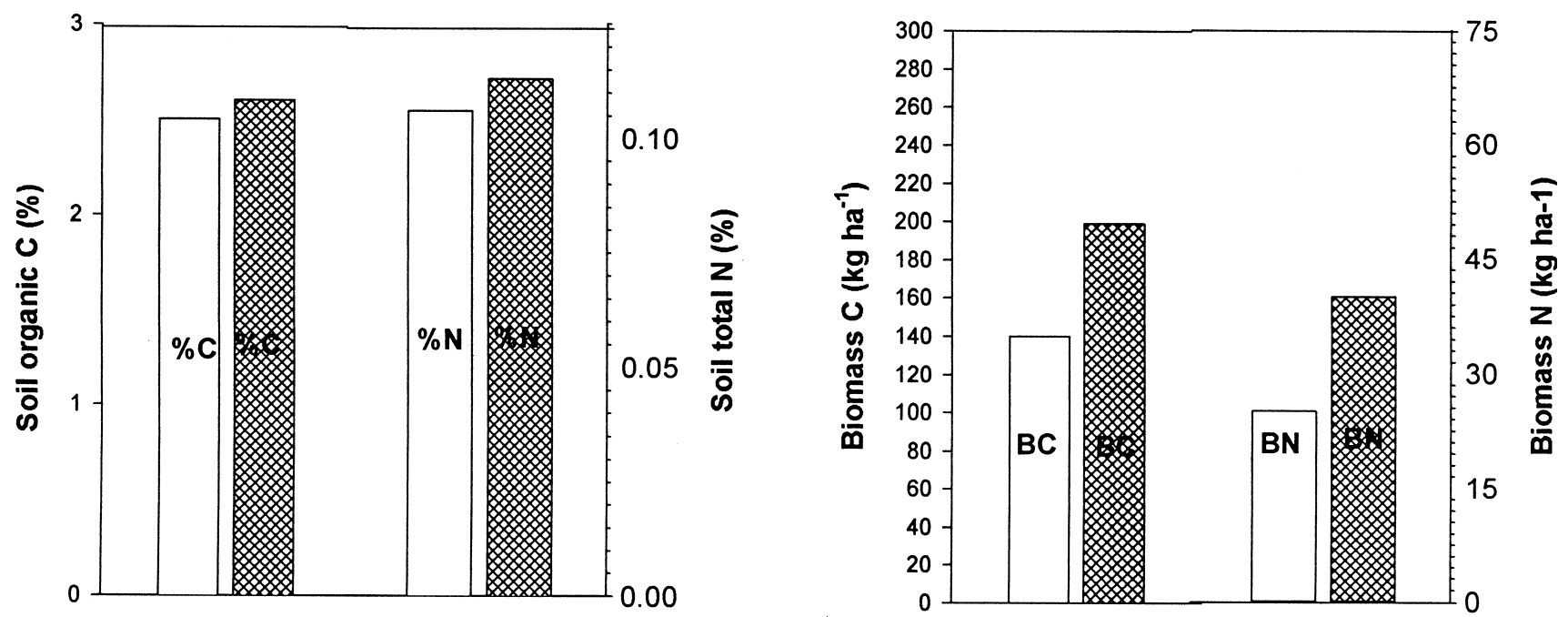

\section{$\square$ burnt incorporated}

Fig. 2. Percentage soil organic $\mathrm{C}$ and $\mathrm{N}$ and biomass $\mathrm{C}$ and $\mathrm{N}$ in Studgaard field soils where straw was burnt or incorporated for 18 years.

ized will be derived from mineral $\mathrm{N}$ immobilized during straw decomposition and some from $\mathrm{N}$ originally present in the $\operatorname{straw}^{26,30)}$. The additional mineralization of $\mathrm{N}$ in straw-treated soils during the $60 \mathrm{~d}$ laboratory incubation was equivalent to more than $20 \mathrm{~kg} \mathrm{~N} \mathrm{ha}^{-1}$ at both sites. Increases of this magnitude in the field, if they occur, are of agronomic significance and would permit fertilizer $\mathrm{N}$ applications to be decreased to some degree.

Similar results were also reported by Saffigna et al. ${ }^{32)}$ for Australian soils. This, and much other similar work, supports the original idea of Powlson and Jenkinson ${ }^{29)}$ that the biomass is a much more sensitive indicator of changing soil conditions than is total soil organic matter content so that the biomass can serve as an "early warning" of such changes long before they may be determined by classical chemical analyses.

\section{Biomass as a sink or source of plant nutrients in low- input agriculture}

Soil nutrient availability in low-input farming systems mainly depends upon the mineralization of crop residues, animal manures and of native soil organic matter. Many farmers outside of the developed world are too poor to afford much inorganic fertilizer so that there is usually a net removal of nutrients from the soil in the harvested crop.
This will often be coupled with a decline in soil organic matter with time as the inputs of organic $\mathrm{C}$ in the crop residues or animal manures are seldom equal to the annual losses of organic $\mathrm{C}$ and $\mathrm{N}$ caused by microbial mineralization and soil erosion. Many farmers are therefore faced with declining soil fertility, with a resulting decrease in crop yield.

It is clear therefore that the correct management of crop residues and animal manures, while important enough in the generally more productive agriculture in temperate regions, is an essential part of the agricultural economics in developing countries, especially in tropical climates. If these organic inputs could be better managed this would have the direct result of improving crop yield, by increasing soil nutrient availability, decreasing erosion, improving soil structure and increasing soil water holding capacity.

The rate and efficiency of mineralization of the nutrients held in crop or animal residues, mediated by the soil microbial biomass, is a key factor in determining the availability of nutrients to crops. It is also becoming widely accepted that the fertility of both natural and agricultural tropical ecosystems depends upon the nutrients being very efficiently cycled within the organic pools of plants, microbes and soil organic matter. In this way, losses of nutrients from the ecosystem are minimized. For example, many tropical soils have exceedingly high $\mathrm{P}$-fixation capacities so that $\mathrm{P}$ is 


\section{RONHAVE}
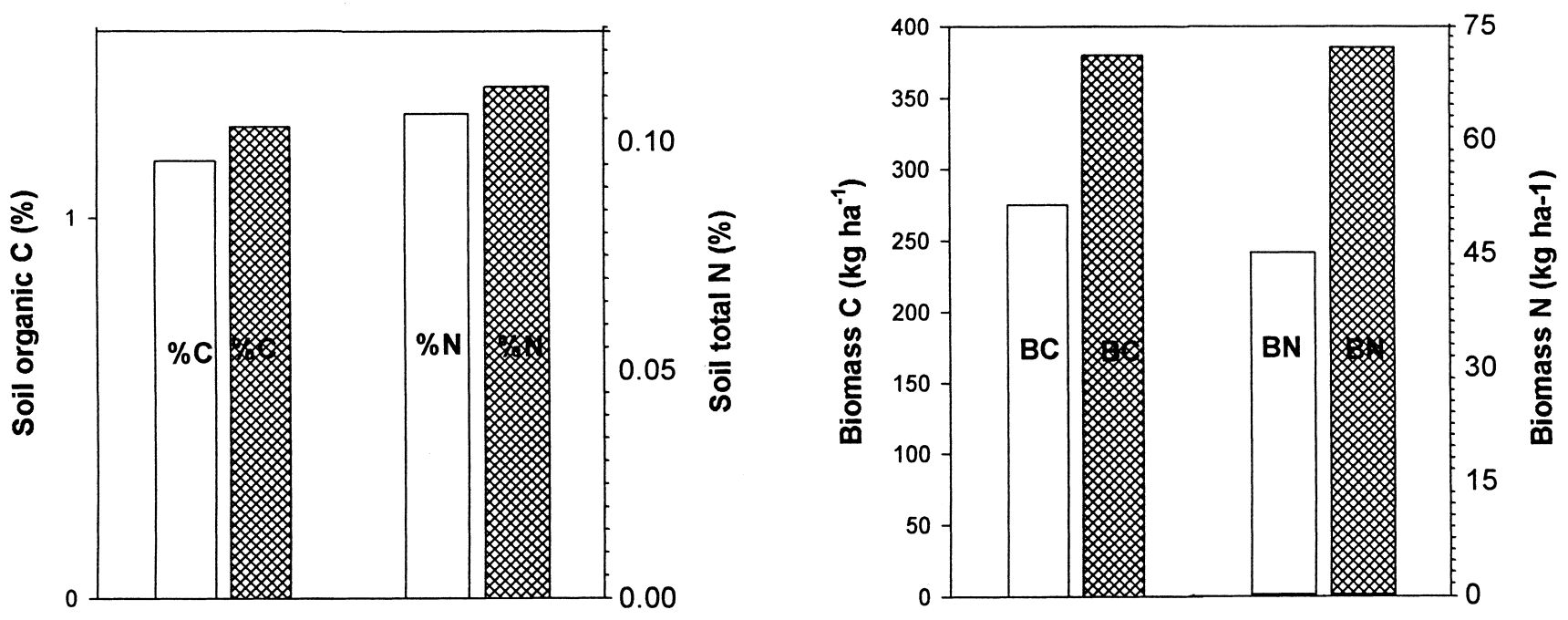

\section{$\square$ burnt}

Fig. 3. Percentage soil organic $\mathrm{C}$ and $\mathrm{N}$ and biomass $\mathrm{C}$ and $\mathrm{N}$ in Rønhave field soils where straw was burnt or incorporated for 18 years.

rapidly and irreversibly fixed and becomes unavailable to plants. However, if cycled within the organic pools, as described above, such losses from plant-available forms can be minimised ${ }^{34)}$.

There is evidence that the microbial biomass constitutes an organic matter pool of potentially available, but protected, plant nutrients in tropical ecosystems. Thus, Singh et al. ${ }^{37)}$ reported that the microbial biomass is an important source of plant-available $\mathrm{N}$ in tropical soils. The biomass declined in size as $\mathrm{N}$ mineralization increased following the rewetting of such soils, precisely during the period when plant growth was most rapid. They therefore considered that the microbial biomass acted both as a sink and a source of nutrients in these nutrient-poor systems. It thus functioned by accumulating and conserving nutrients in a biologically active form during the dry period (large biomass-slow turnover) when the ability of plants to extract nutrients from soil was low. It then released nutrients rapidly once the soils became wet, so stimulating plant productivity (small biomass-fast turnover). Until recently it was not possible to quantify the sizes of the microbial pools of plant nutrients, e.g. N, P, S as they formed during the early decomposition of crop or animal residues. Neither was it possible to monitor the fluxes of nutrients under these conditions as they passed through the biomass, and thence into mineralizable forms. Recent breakthroughs in methodology now make this possible ${ }^{24,26,43)}$, using both unlabelled and isotopicallylabelled plant material and other substrates.

\section{Improving phosphorus fertilizer use efficiency in $P$-fixing soils in Africa}

We are testing the concept of the microbial biomass as a pool of potentially available plant nutrients experimentally in Africa ${ }^{5)}$. Phosphorus is the limiting nutrient in many African soils. This is partly because more is removed in the crop than is replaced by additions of manures or (even more rarely) inorganic fertilizer. Another reason is that many soils chemically fix $\mathrm{P}$ on soil surfaces, where it is then removed from the plant-available pool. One way of possibly overcoming this problem is to apply inorganic fertilizer $\mathrm{P}$ together with an organic fertilizer, e.g. farmyard manure. The organic matter may decrease $\mathrm{P}$ fixation by masking sites which would otherwise fix $P$. The microbial biomass which decomposes the manure will also have a large demand for $\mathrm{P}$ as it grows. Thus $\mathrm{P}$ will thus be immobilized within the microbial cells and so protected from fixation by the soil colloids. As the biomass declines, following exhaustion of the manure, the microbial $\mathrm{P}$ will be mineralized to inorganic $\mathrm{P}$, which plants can use again.

Preliminary results were most encouraging. In both 1997 


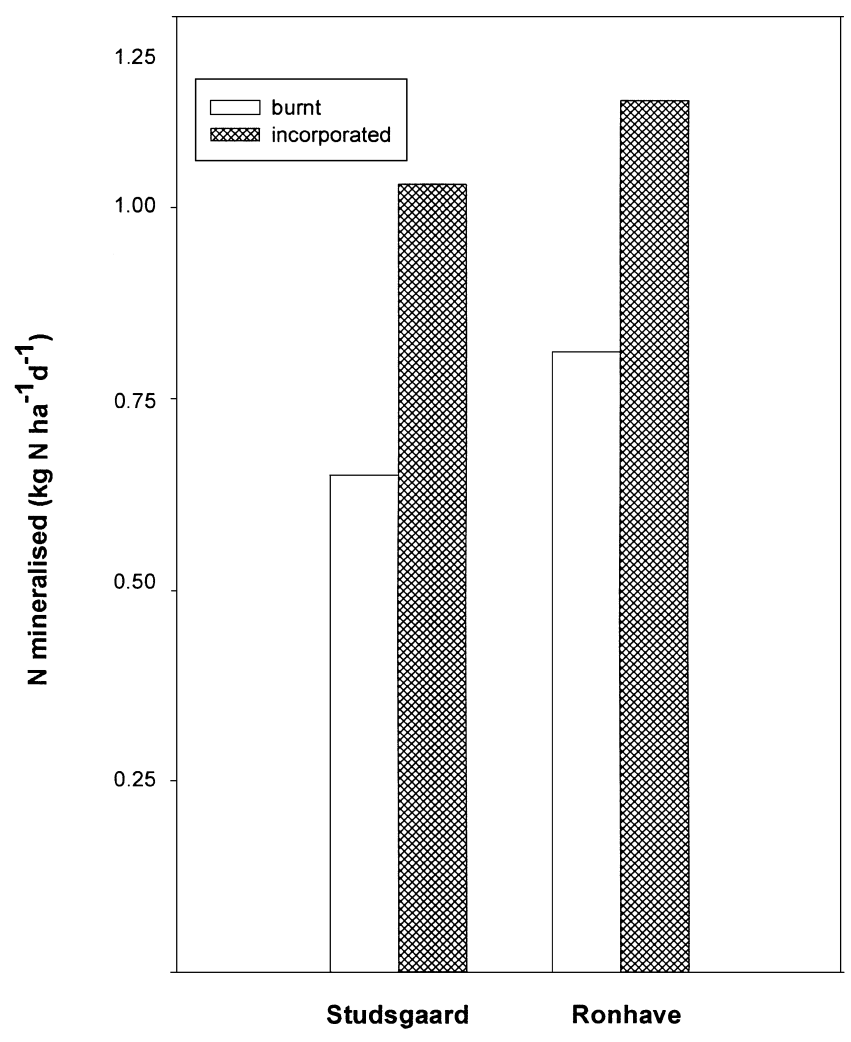

Fig. 4. $\mathrm{N}$ mineralised during 60 days in the laboratory from Danish field soils where straw was burnt or incorporated for 18 years. and 1998 the (Farmyard Manure+P) treatment gave significantly larger yields than when FYM or P were applied singly to a strongly P-fixing soil at Malava (Fig. 6). Differences were much less when the treatments were applied to a non-P fixing soil at Mau Summit. The improvements in yield were certainly not due to the additional inorganic nutrients in the manures. Less than $2 \mathrm{~kg} \mathrm{P} \mathrm{ha}^{-1}$ was supplied in this way.

\section{Turnover of the soil microbial biomass}

The methods available to measure the 'standing crop' of soil microbial biomass, while having their limitations, have given estimates of pool sizes of $\mathrm{C}, \mathrm{N}$ and $\mathrm{P}$ in the biomass which generally fit with perceived reality. They certainly allow us to work towards an understanding of soil nutrient dynamics which would be impossible if we could only study micro-organisms as single species or families in soil ${ }^{27)}$. Linked with this is the concept of biomass turnover, leading to estimates of the flux of nutrients through the biomass. It is really by these processes that soil nutrients are made available to plants by microbial activity. Estimates of biomass turnover times, defined for example for $\mathrm{P}$ as: [(Biomass $\mathrm{P}$ content, $\left.\mathrm{kg} \mathrm{P} \mathrm{ha}{ }^{-1}\right) /($ Annual input of $\mathrm{P}$ into the biomass, $\left.\left.\mathrm{kg} \mathrm{P} \mathrm{ha}^{-1} \mathrm{yr}^{-1}\right)\right]$ and flux of $\mathrm{P}$ through the biomass, as [(Biomass $\mathrm{P}$ content, $\left.\mathrm{kg} \mathrm{P}^{-1}\right) /($ Biomass $\mathrm{P}$ turnover time, $\left.\mathrm{yr}^{-1}\right)$ ] can provide estimates of soil nutrient fluxes in<smiles>O=[Pb](PO)P[Pb]</smiles>

\section{Saturating $P$ - fixing sites}

with rock phosphate

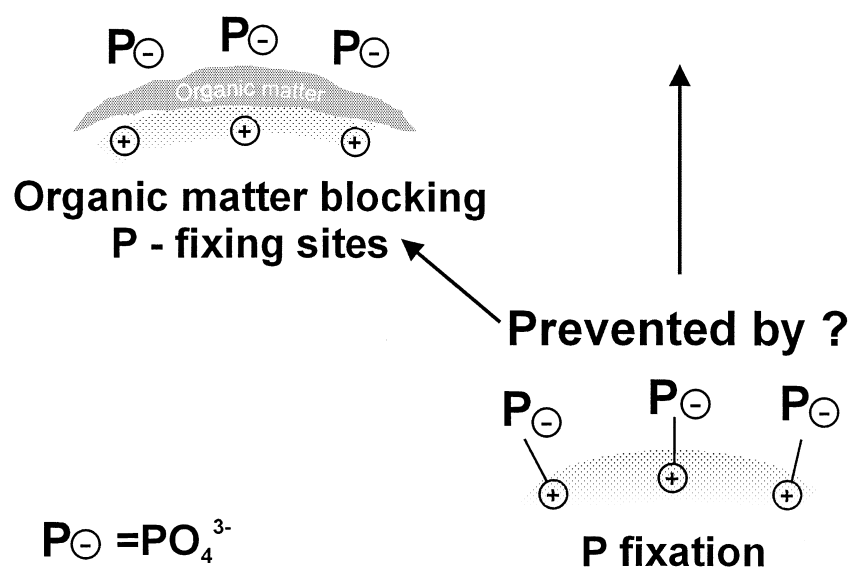

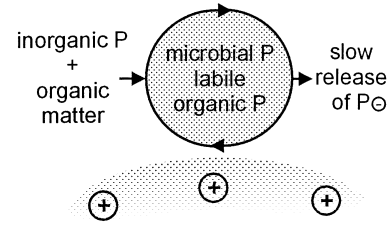

Enhancing biological

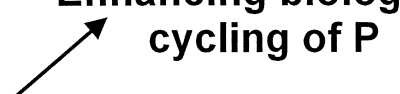

Fig. 5. Possible strategies to overcome the effects of $P$ fixation in soils. 


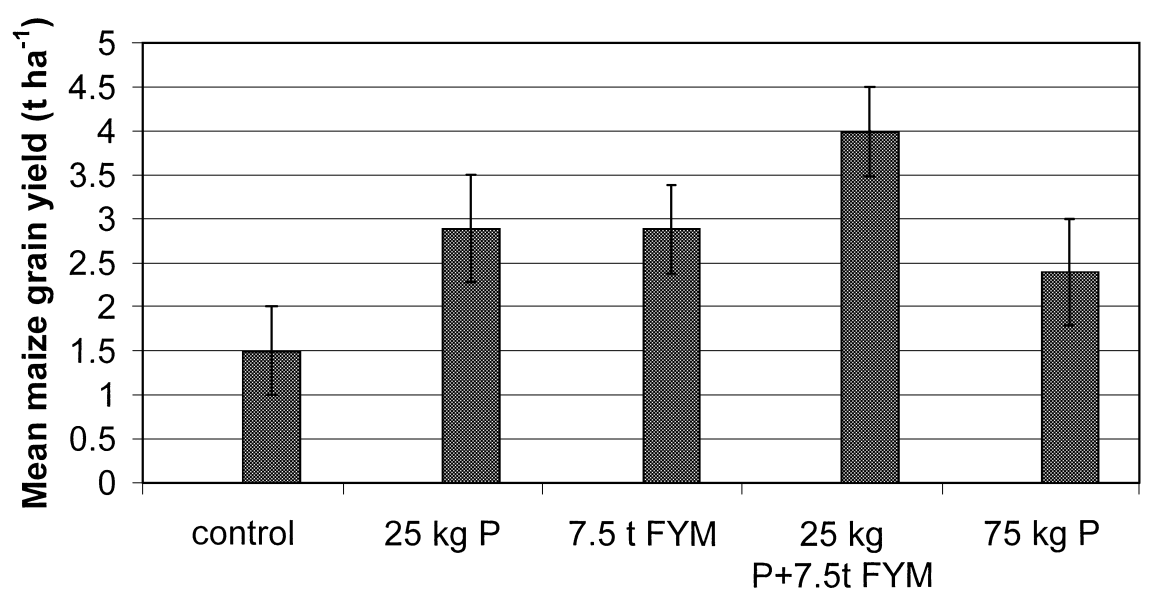

Treatment

Fig. 6. Effect of applied fertilizer $\mathrm{P}$ with or without FYM on maize grain yield at Malava.

agricultural or natural ecosystems.

Jenkinson and Rayner ${ }^{21)}$ proposed a turnover time of 2.5 $\mathrm{yr}$ for biomass $\mathrm{C}$ measured in the Broadbalk Continuous Wheat Experiment under UK field conditions and a turnover time for $\mathrm{N}$ of $1.52 \mathrm{y}$ was proposed for the biomass in soils of the same experiment, again measured under field conditions $^{18)}$. The measurements of turnover of biomass $\mathrm{C}$ were based upon measurements of inputs and declines of ${ }^{14} \mathrm{C}$ in soil as a result of the atomic bomb tests in the $1960 \mathrm{~s}$. At this time a pulse of ${ }^{14} \mathrm{C}$-labelled $\mathrm{C}$ entered the global soil organic matter pool giving, hopefully, a unique chance to undertake these measurements. The turnover time for biomass $\mathrm{N}$ of $1.52 \mathrm{yr}^{18)}$, also obtained under field conditions, was done by adding ${ }^{15} \mathrm{~N}$-labelled inorganic $\mathrm{N}$ fertilizer to the soil in both cases to obtain these values. Full experimental and theoretical details of these and other field measurements of biomass turnover are given by others ${ }^{11,18,21)}$. While it is clear that these and similar measurements are best made under field conditions, the cost, expertise and time required (often several years) often makes this an impossibility. The need to use radioactive isotopes in many cases causes further restrictions, although the increasing use of the nonradioactive isotope ${ }^{13} \mathrm{C}$ may accelerate research into $\mathrm{C}$ dynamics under field conditions. Certainly, any proposal to measure biomass $\mathrm{P}$ dynamics, using ${ }^{32} \mathrm{P}$ or ${ }^{33} \mathrm{P}$ in the field would now face a plethora of restrictions and regulations which would daunt all but the strongest hearted.

Recently we developed a procedure (based on that proposed by $\mathrm{Wu}^{42)}$ ) to measure the turnover times of biomass $\mathrm{P}$ and biomass $\mathrm{C}$ simultaneously in the same soil, under the same conditions in the laboratory ${ }^{22}$. The method involves addition of ${ }^{14} \mathrm{C}$-labelled substrates (in this case glucose) to soil containing $\mathrm{KH}_{2}{ }^{32} \mathrm{PO}_{4}$ which has been allowed to equilibrate for $5 \mathrm{~d}$ with unlabelled native soil inorganic $\mathrm{P}$ prior to glucose addition. The apparent turnover times of biomass $\mathrm{C}$ and $\mathrm{P}$ were estimated by applying first-order kinetics rate equations to the declines in ${ }^{32} \mathrm{P}$ - and ${ }^{14} \mathrm{C}$-labelled biomasses at $25^{\circ} \mathrm{C}$ and $40 \%$ water holding capacity (WHC). Assuming that turnover times of biomass under field conditions in a temperate climate are about 4 times slower than under the above laboratory conditions, Chaussod et al. ${ }^{11)}$, this gives mean field turnover rates for both native and recently synthesised biomass $\mathrm{P}$ of about $0.4 \mathrm{yr}$ and for biomass $\mathrm{C}$ of about $1.0 \mathrm{yr}$, measured in a Rothamsted soil of about $23 \%$ clay. Using these values, the mean biomass $\mathrm{P}$ flux through 6 UK arable soils was about $40 \mathrm{~kg} \mathrm{P} \mathrm{ha}^{-1} \mathrm{yr}^{-1}$ and about 140 $\mathrm{kg} \mathrm{P} \mathrm{ha} \mathrm{yr}^{-1}$ for UK grasslands.

The faster turnover time for $\mathrm{P}$ than $\mathrm{C}$ seems reasonable as the $\mathrm{P}$ will be almost entirely within the cell membranes and cytoplasm of the micro-organisms, while the $\mathrm{C}$ will also be an important constituent of the cell wall. Microbial cell walls are known to be much more stable in soil than the intracellular components ${ }^{16)}$. The results strongly indicate that the microbial biomass is far from being a static component of the total soil organic matter pool and that the flux of nutrients through it can be surprisingly large. Phosphorus coming from biomass turnover will help replenish soil inorganic $\mathrm{P}$ pools.

It must be emphasised that our ideas about the measurement of biomass turnover times and the quantification of fluxes of nutrients through the biomass are still evolving. In particular the fluxes of $\mathrm{P}$ through the biomass as measured by ${ }^{32} \mathrm{P}$ seem large, although there are few, if any, similar measurements to serve as comparisons. Calculated fluxes of 
Table 2. Biomass turnover times and $\mathrm{C}$ and $\mathrm{P}$ fluxes.

\begin{tabular}{|c|c|c|c|c|}
\hline \multirow[t]{3}{*}{ Soils } & \multicolumn{2}{|c|}{ Turnover times } & \multicolumn{2}{|c|}{ Flux through biomass } \\
\hline & Biomass $\mathrm{C}$ & 3iomass $\mathrm{P}$ & $\mathrm{C}$ & $\mathrm{P}$ \\
\hline & \multicolumn{2}{|c|}{ Years } & \multicolumn{2}{|c|}{$\mathrm{kg} \mathrm{ha}^{-1} \mathrm{y}^{-1}$} \\
\hline Arable & 0.94 & 0.39 & 300 & 44 \\
\hline Grassland & 0.94 & 0.39 & 927 & 146 \\
\hline
\end{tabular}

P through the biomass, usually based on 'standing crop' measurements of biomass $\mathrm{P}$ and an assumed turnover time of 1.5-2.5 years ${ }^{9,38)}$ are generally around $10 \mathrm{~kg} \mathrm{P} \mathrm{ha}^{-1} \mathrm{yr}^{-1}$ for temperate arable soils and $25 \mathrm{~kg} \mathrm{P} \mathrm{ha}^{-1} \mathrm{yr}^{-1}$ for grassland or forest. More work is needed to evaluate these discrepancies. We also do not know the proportions of nutrients that are made available to plants during biomass turnover. Some will be sorbed by the soil, some will be utilized directly by the soil microbial biomass, and some may be lost by leaching or erosion.

\section{Conclusions}

The microbial biomass concept was introduced as a viable, working method in soil science nearly thirty years $\mathrm{ago}^{19)}$. It has therefore stood the test of time. It is a 'black box' or holistic approach, measuring the entire population, and with suitable modifications, the nutrient fluxes through it. Therefore, the approach makes no attempt to take any account of microbial diversity and its implications in the functioning of the soil microorganisms or their interactions. In some ways this is a clear weakness, in others it is most certainly a strength.

The newer approaches of measuring microbial diversity have developed rapidly. Initially, only crude microscopic measurements were available. However, the newer molecular approaches, such as microbial fatty acid and nucleic acid based measurements opened up the biomass 'black box' in ways which were, hitherto, impossible.

In some rather obvious cases, such as single processes like biological $\mathrm{N}_{2}$-fixation, or the introduction and monitoring of a single introduced organism, the benefits of diversity over biomass measurements may be quite obvious. However, in other more complex situations, such as organic matter mineralization, where suites of organisms or genes may be involved the 'black box' approach is still a very valuable one. Certainly, the newer methodologies are going to play a key role in the future. However, I am equally sure that soil will continue to throw us more questions than answers, whichever methodologies we may ultimately be capable of developing.

\section{Acknowledgements}

IACR receives grant-aided support from the Biotechnology and Biological Sciences Research Council of the United Kingdom. I also especially thank Profs. D.S. Jenkinson and D.S. Powlson for their contributions to this work, in addition to the many visiting scientists who contributed much also.

\section{References}

1) Adams, T.McM. and R.J. Laughlin. 1981. The effects of agronomy on the carbon and nitrogen contained in the soil biomass. J. Agric. Sci. 97: 319-327.

2) Amato, M. and J.N. Ladd. 1988. Assay for microbial biomass based on ninhydrin-reactive nitrogen in extracts of fumigated soils. Soil Biol. Biochem. 20: 107-114.

3) Anderson, J.M. and J.S. Ingram. 1992. Tropical soil biology and fertility. A handbook of methods. CAB International.

4) Anderson, T.H. and K.H. Domsch. 1989. Ratios of microbial biomass carbon to total organic carbon in arable soils. Soil Biol. Biochem. 21: 471-479.

5) Ayaga, G. 2000. Improving the efficiency of phosphate utilization in low-input maize production in Kenya. Ph.D. thesis. University of Nottingham.

6) Ayanaba, A., S.B. Tuchwell and D.S. Jenkinson. 1976. The effect of clearing and cropping on the organic reserves and biomass of tropical forest soils. Soil Biol. Biochem. 8: 519-525.

7) Brookes, P.C., A. Landman, G. Pruden and D.S. Jenkinson. 1985. Chloroform fumigation and the release of soil nitrogen: a rapid direct extraction method to measure microbial biomass nitrogen in soil. Soil Biol. Biochem. 17: 837-842.

8) Brookes, P.C., D.S. Powlson and D.S. Jenkinson. 1982. Measurement of microbial biomass phosphorus in soil. Soil Biol. Biochem. 14: 319-321.

9) Brookes, P.C., D.S. Powlson and D.S. Jenkinson. 1984. Phosphorus in the soil microbial biomass. Soil Biol. Biochem. 16: 169175.

10) Chapman, S.J. 1987. Microbial sulphur in some Scottish soils. Soil Biol. Biochem. 19: 301-305.

11) Chaussod, R., S. Houot., G. Guiraud and J.M. Hetier. 1988. Size and turnover of the microbial biomass in agricultural soils: laboratory and field measurements, p. 323-338. In D.S. Jenkinson and K.A. Smith (ed.), Nitrogen efficiency in agricultural soils. Elsevier.

12) Hirsch, P.R., M.J. Jones, S.P. McGrath and K.E. Giller. 1993. Heavy metals from past applications of sewage sludge decrease the genetic diversity of Rhizobium leguminosarum biovar trifolii populations. Soil Biol. Biochem. 25: 1485-1490.

13) Insam, H., D. Parkinson and K.H. Domsch. 1989. Influence of macroclimate on soil microbial biomass. Soil Biol. Biochem. 21: 211-221.

14) Inubushi, K., P.C. Brookes and D.S. Jenkinson. 1991. Soil microbial biomass $\mathrm{C}, \mathrm{N}$ and ninhydrin- $\mathrm{N}$ in aerobic and anaerobic soils measured by the fumigation-extraction method. Soil Biol. Biochem. 23: 737-741.

15) Jenkinson, D.S. 1977. The soil biomass. New Zealand Soil News 25: $213-218$. 
16) Jenkinson, D.S. and J.N. Ladd. 1981. Microbial biomass in soil: measurement and turnover, p. 415-471. In E.A. Paul and J.N. Ladd (ed.), Soil Biochemistry, Vol. 5. Marcel Dekker, New York.

17) Jenkinson, D.S. and J.M. Oades. 1979. A method for measuring adenosine triphosphate in soil. Soil Biol. Biochem. 11: 193-199.

18) Jenkinson, D.S. and L.C. Parry. 1989. The nitrogen cycle in the Broadbalk Wheat Experiment: a model for the turnover of nitrogen through the soil microbial biomass. Soil Biol. Biochem. 21: 535-541.

19) Jenkinson, D.S. and D.S. Powlson. 1976. The effects of biocidal treatments on metabolism in soil. V. A method for measuring soil biomass. Soil Biol. Biochem. 8: 209-213.

20) Jenkinson, D.S., D.S. Powlson and R.W.M. Wedderburn. 1976. The effects of biocidal treatments on metabolism in soil. III. The relationship between soil biovolume, measured by optical microscopy, and the flush of decomposition caused by fumigation. Soil Biol. Biochem. 8: 189-202.

21) Jenkinson, D.S. and J.H. Rayner. 1977. The turnover of soil organic matter in some of the Rothamsted Classical Experiments. Soil Science 123: 298-305.

22) Kouno, K., J. Wu and P.C. Brookes. 2000. The turnover of soil microbial biomass phosphorus. Soil Biol. Biochem. (in press).

23) Martens, R. 1985. Limitations in the application of the fumigation technique for biomass estimations in amended soils. Soil Biol. Biochem. 17: 57-63.

24) Ocio, J.A. and P.C. Brookes. 1990a. An evaluation of methods for measuring the microbial biomass in soils following recent additions of wheat straw and the characterization of the biomass that develops. Soil Biol. Biochem. 22: 685-694.

25) Ocio, J.A., P.C. Brookes and D.S. Jenkinson. 1991a. Field incorporation of straw and its effects on soil microbial biomass and soil inorganic N. Soil Biol. Biochem. 23: 171-176.

26) Ocio, J.A., J. Martinez and P.C. Brookes. 1991b. Contribution of straw-derived $\mathrm{N}$ to total microbial biomass $\mathrm{N}$ following incorporation of cereal straw to soil. Soil Biol. Biochem. 23: 655-659.

27) Powlson, D.S. 1993. The soil microbial biomass—before, beyond and back, p. 275. In K. Ritz, J. Dighton and K.E. Giller (ed.), Beyond the Biomass; Compositional and Functional Analyses of Soil Microbial Communities. John Wiley and Sons.

28) Powlson, D.S., P.C. Brookes and B. Christensen. 1987. Measurement of soil microbial biomass provides an early indication of changes in total organic matter due to straw incorporation. Soil Biol. Biochem. 19: 159-164.

29) Powlson, D.S. and D.S. Jenkinson. 1976. The effects of biocidal treatments on metabolism in soil. II. Gamma irradiating autoclav- ing, air-drying and fumigation. Soil Biol. Biochem. 8: 179-188.

30) Powlson, D.S., D.S. Jenkinson, G. Pruden and A.E. Johnston. 1985. The effect of straw incorporation on the uptake of nitrogen by winter wheat. J. Sci. Food Agric. 36: 26-30.

31) Ross, D.J., K.R. Tate, T. Cairns and E.A. Pansia. 1980. Microbial biomass estimations in soil from tussock grassland by three biochemical procedures. Soil Biol. Biochem. 12: 275-283.

32) Saffigna, P.G., D.S. Powlson, P.C. Brookes and G.A. Thomass. 1989. Influence of tillage and sorghum residues on soil organic matter and soil microbial biomass in an Australian vertisol. Soil Biol. Biochem. 21: 759-765.

33) Saggar, S., J.R. Betteny and J.W.B. Stewart. 1981. Measurement of microbial sulphur in soil. Soil Biol. Biochem. 13: 493-498.

34) Sanchez, P.A. 1976. Properties and management of soils in the tropics. John Wiley and Sons Ltd.

35) Sarathchandra, S.U., K.W. Perrot and M. Upsdell. 1984. Microbiological and biochemical characteristics of a range of New Zealand soils under established pasture. Soil Biol. Biochem. 16: 177-183.

36) Shen, S-M., P.C. Brookes and D.S. Jenkinson. 1987. Soil respiration and the measurement of microbial biomass $\mathrm{C}$ by the fumigation technique in fresh and in air-dried soil. Soil Biol. Biochem. 19: 153-158.

37) Singh, J.S., A.S. Raghubanski, R.S. Singh and S.C. Srivasta. 1989. Microbial biomass acts as a source of plant nutrients in dry tropical forest and savannah. Nature 338: 499-500.

38) Srivastava, S.C. and J.S. Singh. 1991. Microbial C, N and P in dry tropical forest soils: effects of alternate land uses and nutrient flux. Soil Biol. Biochem. 23: 117-124.

39) Vance E.D., P.C. Brookes and D.S. Jenkinson. 1987a. Microbial biomass measurements in forest soils: the use of the chloroform fumigation-incubation method in strongly acid soils. Soil Biol. Biochem. 19: 697-702.

40) Vance, E.D., P.C. Brookes and D.S. Jenkinson. 1987b. An extraction method for measuring soil microbial biomass C. Soil Biol. Biochem. 19: 703-707.

41) Wu, J., R.G. Joergensen, B. Pommering, R. Chaussod and P.C. Brookes. 1990. Measurement of soil microbial biomass $C$ by fumigation-extraction - an automated procedure. Soil Biol. Biochem. 22: 1167-1169.

42) Wu, J. 1991. The turnover of soil organic carbon. Ph.D. thesis. University of Reading.

43) Wu, J., P.C. Brookes and D.S. Jenkinson. 1993. Formation and destruction of microbial biomass during the decomposition of glucose and ryegrass in soil. Soil Biol. Biochem. 28: 885-892. 